Pustaka Karya: Jurnal Ilmiah Ilmu Perpustakaan dan Informasi Vol. 8 No. 1, Juni 2020, Hal. 1-14

http://dx.doi.org/10.18592/pk.v7i15.3709

ISSN (p) : 2089-5216 | ISSN (e) : 2723-7699

\title{
Membangun koleksi taman bacaan masyarakat yang berbasis inklusi sosial (building public park reading collection based on social inquiry) ${ }^{1}$ Yunus Winoto, ${ }^{2}$ Sukaesih \\ 1, 2, 3 Program Studi Perpustakaan dan Sains Informasi, Universitas Padjadjaran ${ }^{1} \mathrm{Jl}$. Raya Bandung Sumedang KM.21, Kab, Sumedang, Jawa Barat 45363 Email: ${ }^{1}$ yunuswinoto@gmail.com
}

\begin{abstract}
The purpose of this research is to find out collection development activities which include the stages of analyzing user needs, selection policies, selection of library materials, procurement of library materials, weeding library materials and evaluating collection development. The location of this research was conducted in eight (8) community reading parks in West Bandung Regency. The method used in this study uses qualitative methods with the type of phenomenological research. The collection technique is carried out through observation, interviews and through literature study. Based on the results of the study note that the stages of collection development carried out by the managers in the community reading park (TBM) of West Bandung Regency only at the stages of analysis of user needs, selection and procurement of library materials. Whereas the collection policy stage has not been done in writing because the data collection source is also from the manager and the amount is also limited, for weeding activities so far have not been done because the number of collections and for evaluation activities are only done by asking questions about the availability of collections needed by users. However, in developing a collection of TBM managers provide space and open access for users to provide input in providing the collection needed.
\end{abstract}

Keywords: collection; collection development;community reading parks; social inclusion

\begin{abstract}
ABSTRAK
Tujuan penelitian ini adalah untuk mengetahuai kegiatan pengembangan koleksi yang meliputi tahapan analisis kebutuhan pengguna, kebijakan seleksi, seleksi bahan pustaka, pengadaan bahan pustaka, penyiangan bahan pustaka serta evaluasi pengembangan koleksi. Lokasi penelitian ini dilakukan pada delapan (8) taman bacaan masyarakat di Kabupaten Bandung Barat. Metode yang digunakan dalam penelitian ini menggunakan metode kualitatif dengan jenis penelitian fenomenologi. Teknik pengumpulan dilakukan dilakukan melalui observasi, wawancara serta melalui studi kepustakaan. Berdasarkan hasil penelitian diketahui bahwa tahapan pengembangan koleksi yang dilakukan para pengelola di taman bacaan masyarakat (TBM) Kabupaten Bandung Barat hanya pada tahapan analisis kebutuhan pengguna, seleksi dan pengadaan bahan pustaka. Sedangkan untuk tahapan kebijakan koleksi belum dilakukan secara tertulis karena sumber pendataan juga dari pengelola dan jumlahnya juga terbatas, untuk kegiatan penyiangan selama ini belum dilakukan karena jumlah koleksi serta untuk kegiatan evaluasi hanya dilakukan dengan mengajukan pertanyaan mengenai ketersediaan koleksi yang dibutuhkan para pengguna. Namun demikian dalam melakukan pengembangan koleksi pengelola TBM memberikan ruang dan akses yang terbuka bagi pengguna dalam memberikan masukan dalam penyediaan koleksi yang dibutuhkan.
\end{abstract}

Kata Kunci: inklusi sosial; koleksi; pengembangan koleksi; taman bacaan masyarakat 


\section{PENDAHULUAN}

Kabupaten Bandung Barat (KBB) adalah merupakan salah satu kabupaten yang ada di wilayah provinsi Jawa Barat dengan ibukota kabupaten terletak di Kecamatan Ngamprah. Luas wilayahnya sekitar 1.305,77 Km2 atau 130.577,40 Ha, jumlah penduduk sebanyak 1,4 juta jiwa dan jumlah kecamatan sebanyak 16 kecamatan. Sebagai salah satu kabupaten baru hasil pemekaran dari Kabupaten Bandung, Kabupaten Bandung Barat memiliki taman bacaan masyarakat yang paling banyak yakni sebanyak 52 TBM yang tersebar di hampir seluruh kecamatan di wilayah KBB. Namun demikian dari jumlah tersebut TBM menurut ketua forum TBM Kabupaten Bandung Barat yaitu Awaludin menyatakan bahwa, “... dari sejumlah 52 TBM yang ada di Kabupaten Bandung Barat telah aktif dalam kegiatan forum TBM baru sekitar 29 TBM”. (Sumber : Awaludin, wawancara, tanggal 18 November tahun 2019).

Berbicara tentang taman bacaan masyarakat (TBM) secara sederhana dapat diartikan sebagai tempat yang dibuat oleh pemerintah, swadaya masyarakat maupun perseorangan untuk menyediakan akses bahan bacaan bagi masyarakat sekitar sebagai sarana pembelajaran sepanjang hayat dalam rangka meningkatkan kualitas hidup masyarakat di sekitar lokasi taman bacaan masyarakat. Adapun jika dilihat dari dari pengelolaannya taman bacaan masyarakat ini terdiri dari dua yakni taman bacaan masyarakat mandiri yakni suatu taman bacaan masyarakat yang didirikan dan dikelola oleh peserorangan atau swadaya masyarakat sebagai bentuk kepedulian terhadap pemberdayaan masyarakat melalui penyediaan bahan bacaan serta taman bacaan masyarakat yang didirikan pemerintah yang juga merupakan pusat kegiatan belajar mengajar (PKBM). Biasanya taman bacaan masyarakat jenis ini keberadaannya dibawah koordinasi kemdikbud kabupaten. Ada beberapa tujuan diselenggarakannya taman bacaan masyarakat menurut Depdikbud (2006) yakni 1) untuk membangkitkan dan meningkatkan minat baca masyarakat sehingga tercipta masyarakat yang cerdas dan selalu mengikuti perkembangan ilmu pengetahuan dan teknologi; 2) sebagai wadah kegiatan belajar masyarakat 3) untuk mendukung peningkatkan kemampuan aksarawan baru dalam pemberantasan buta aksara sehingga tidak menjadi buta aksara kembali.

Dalam pengelolaan taman bacaan masyarakat (TBM) yang ada di wilayah Kabupaten Bandung Barat para pengelola dalam melakukan kegiatannya tidak bisa bekerja sendiri namun memerlukan bantuan atau kehadiran pihak lain seperti tokoh masyarakat maupun para relawan yang mendukung keberlangsungan penyeleng-garan taman bacaan tersebut. Hal ini dapat dipahami karena dalam pengelolaan TBM tidak cukup hanya dengan tenaga namun membutuhkan biaya atau dana, baik untuk kegiatan operasional SDM maupun untuk penyediaan dan pemeliharaan fasilitas serta untuk pembelian koleksi atau bahan bacaan. Oleh karena itu pihak pengelola juga harus aktif dalam mensosialisasikan TBM-nya pada pihak lain atau mitra untuk memperoleh bantuan dana maupun fasilitas. Upaya ini pernah dilakukan forum TBM Kabupaten Bandung Barat dengan melakukan kerjasama dengan perpusSeru sehingga mendapat bantuan 11 komputer untuk 11 TBM untuk membantu pengguna TBM belajar komputer dan mengakses sumber informasi melalui internet.

Tujuan dari penyelenggarakaan taman bacaan masyarakat hakekatnya adalah untuk pemberdayaan masyarakat melalui penyediaan bahan-bahan bacaan. Dengan memanfaatkan bahan bacaan yang ada di perpustakaan diharapkan masyarakat mendapat pengetahuan dan keterampilan dalam mendukung pekerjaannya sehari-hari sehingga semakin produktif dan pada gilirannya dapat meningkatkan kesejahteraanya. Untuk mencapai hal tersebut, maka TBM harus menyediakan koleksi atau bahan bacaan yang sesuai dengan kebutuhan masyarakat penggunanya melalui kegiatan yang disebut dengan pengembangan koleksi. 
Pengembangan koleksi merupakan bagian penting untuk kelangsungan taman bacaan masyarakat serta meningkatkan mutu koleksinya agar keberadaan taman bacaan masyarakat tetap menjadi bagian dari aktifitas mereka sehari-hari. Oleh karena itu dalam pengembangan koleksi harus berorientasi pada kebutuhan masyarakat penggunanya serta sesuai dengan perkembangan zaman. Hal senada juga dikemukakan Soeatminah (1992) yang menyatakan bahwa salah satu prinsip pembinaan koleksi yang perlu diperhatikan adalah prinsip kemutakhiran, maksudnya bahan pustaka yang dihimpun hendaknya sesuai dengan perkembangan ilmu pengetahuan, informasi dan teknologi agar pemakai dapat memperoleh informasi yang sesuai dengan perkembangan zaman

Apabila tujuan dari keberadaan taman bacaan masyarakat adalah untuk mendukung pemberdayaan masyarakat melalui penyediaan koleksi dan bahan bacaan lainnya, maka pengembangan koleksi yang dilakukan harus berbasis inklusi sosial, artinya pengembangan koleksi yang dilakukan harus dirancang agar ketersediaan koleksi dapat memiliki nilai kemanfaatan yang tinggi bagi masyarakat dalam rangka meningkatkan kualitas dan kesejahteraanya atau dengan kata lain pengembangan koleksi berbasis inklusi sosial adalah suatu sebuah upaya mendorong masyarakat untuk secara mandiri manfatkan koleksi dan bahaan bacaan lainnya yang ada di taman bacaan masyarakat (TBM untuk meningkatkan kualitas dan kesejahteraan hidupanya.

Oleh karena demikian berdasarkan uraian di atas peneliti tertarik untuk mengkaji tentang kegiatan pengembangan koleksi pada taman bacaan masyarakat yang berbasis inkulis sosial. Penelitian ini dilakukan terhadap delapan (8) taman bacaan masyarakat yang ada di kabupaten Bandung Barat yakni TBM Pengelolaan lingkungan Cibungur, TBM Gunung Ilmu, TBM Bhakti Mandala Muda, TBM Bening Saguling, TBM Pasir Ipis, TBM Tali Raksa Aksara, TBM Sahabat Pena serta TBM Citapen Berkah. Sedangkan mengenai kegiatan pengembangan koleksi yang dimasudkan adalah suatu kegiatan mengidentifikasi kebutuhan pengguna taman bacaan masyarakat. Ada enam fokus penelitian yang dikaji yakni tahapan analisis kebutuhan masyarakat, pembuatan kebijakan seleksi, seleksi bahan pustaka, pengadaan bahan pustaka, penyiangan bahan pustaka serta evaluasi pengembangan koleksi. Adapun metode yang digunakan dalam penelitian ini menggunakan metode kualitatif dengan jenis penelitian fenomenologi yakni mengkaji pengalaman pelaku dalam hal ini pengeloila TBM dalam melakukan pengembangan koleksi perpustakaan.

\section{TINJAUAN PUSTAKA}

Penelitian ini mengkaji tentang kegiatan pengembangan koleksi yang berbasis inklusi sosial pada taman bacaan masyarakat di Kabupaten bandung Barat. Adapun dalam mengkaji tentang penelitian ini peneliti berangkat dari beberapa penelitian terdahulu. Ada beberapa penelitian sebelumnya yang menjadi dasar tinjauan penelitian terdahulu seperti penelitian yang berjudul Motivasi Komunitas Lentera Mimpi Purwakarta Mendirikan Taman Baca Green Library. Ai Nuraeni. 2018. Universitas Padjadjaran. Metode penelitian yang digunakan adalah metode kualitatif dengan pendekatan studi kasus. Tujuan penelitian ini untuk mengetahui motif tujuan (in order to motive) dan motif alasan (because motive) dalam mendirikan Taman Baca Green Library. Hasil penelitian ini menunjukkan bahwa motif pendirian Taman Baca Green Library yaitu motif tujuan (in order to movite) mereka untuk lebih sadar pentingnya pendidikan, meningkatan minat baca, memfasilitas anak-anak untuk membaca, kemudian motif alasan (because motive) mereka karena kurangnya kesadaran akan pentingnya pendidikan, minimnya minat baca, ajakan dari teman, ,mengaplikasikan Tri Darma Perguruan Tinggi yaitu pengabdian kepada masyarakat, sesuai hadits Rasul, tidak ada kegiatan lain untuk anak-anak, kurangnya fasilitas membaca.

Penelitian kedua berjudul Konstruksi Makna Pegiat Perpustakaan Jalanan di Kota Bandung. Nugraha Dwi Saputra. 2017. Universitas Padjadjaran. Metode penlitian yang digunakan adalah 
kualitatif dengan pendekatan fenomenologi. Tujuan penelitian ini untuk mengetahui makna pegiat perpustakaan jalanan bagi dirinya, untuk mengetahui motif yang mendasari pendirian Perpustakaan Jalanan Bandung dan untuk mengetahui pengalaman mengelola Perpustakaan Jalanan Bandung. Hasil penelitian ini menemukan adanya tiga makna pegiat perpustakaan jalanan yaitu penyedia ruang alternatif, penyegar pikiran dan manusia baru. Sedangkan motif didirikannya Perpustakaan Jalanan Bandung terbagi menjadi dua motif yaitu motif alasan dan motif tujuan. Motif alasan ialah masyarakat menunjukan sulit mengakses informasi, banyak buku pribadi yang tidak terpakai, dan kritik terhadap ruang publik. Motif tujuan didirikannya Perpustakaan Jalanan Bandung yaitu mempermudah akses informasi bagi semua orang dan membuat tempat baca alternatif. Pengalaman yang pernah dialami pegiat Perpustakaan Jalanan Bandung selaman tujuh tahun mengelola Perpustakaan Jalanan Bandung ialah lapak buku gratis, mengadakan acara diskusi dan sharing informasi, membuat kegiatan pagelaran seni, mengadakan acara berbagi dengan sesama, dan mengadakan acara solidaritas.

Penelitian ketiga berjudul Motivasi Pengelola Dalam Mendirikan TBM di Kabupaten Bandung Barat, Eca Luciana, 2019, Universitas Padjadjaran. Penelitian ini bertujuan untuk mengetahui motivasi pengelola dalam mendirikan Taman Bacaan Masyarakat. Penelitian ini dilakukan pada Taman Bacaan Masyarakat yang ada di Kabupaten Bandung Barat. Metode yang digunakan dalam penelitian menggunakan pendekatan kualitatif dengan jenis penelitian fenomenologi. Teknik pengumpulan data dilakukan memalui observasi, wawancara dan melalui studi kepustakaan. Berdasarkan hasil penelitian terungkap bahwa motif tujuan (in order to motive) pengelola mendirikan TBM adalah yaitu untuk memfasilitasi masyarakat melalui TBM, meningkatkan minat baca masyarakat serta untuk menyediakan sarana yang dapat bermanfaat bagi masyarakat. Sedangkan untuk motif alasan (because motive) pengelola mendirikan

TBM yaitu dikarenakan kurangnya informasi atau pengetahuan masyarakat, untuk melestarikan budaya membaca, menambah pengetahuan anak, untuk membatasi pergaulan anak yang tidak terkontrol, tingginya angka buta aksara, serta masih kurangnya kesadaran masyarakat akan pentingnya pendidikan.

Berdasarkan ketiga penelitian terdahulu sebagimana yang diuraikan di atas jika dikaitkan dengan penelitian yang penulis lakukan ada beberapa perbedaan seperti penelitian yang kami lakukan menekankan pada kegiatan pengembangan koleksi yang berbasis inklusi dan penelitian belum menjadi bahasan peneliti sebelumnya sehingga topik yang penulis angkat sangat layak untuk dilanjutkan sebagai penelitian.

\section{A. TAMAN BACA MASYARAKAT}

Menurut Sutarno (2008) Taman Baca Masyarakat adalah tempat yang sengaja dibuat pemerintah, perorangan atau swakelola dan swadaya masyarakat untuk menyediakan bahan bacaan dan menumbuhkan minat baca kepada masyarakat yang berada di sekitar Taman Baca Masyarakat (TBM). Sedangkan menurut Buku Pedoman Penyelenggaraan Taman Bacaan Masyarakat (2006) Taman Bacaan Masyarakat adalah sebuah tempat/wadah yang didirikan dan dikelola baik masyarakat maupun pemerintah untuk memberikan akses layanan bahan bacaan bagi masyarakat sekitar sebagai sarana pembelajaran seumur hidup dalam rangka peningkatan kualitas hidup masyarakat di sekitar TBM. Jadi tujuan dari penyelenggaraan TBM adalah untuk meningkatkan kualitas hidup kesejahteraan masyarakat melalui penyediaan koleksi atau bahan bacaan lainnya.

Kemudian jika dilihat dari jenisnya taman bacaan masyarakat terdiri dari beberapa jenis yakni sebagai berikut 1) tBM Mandiri yakni TBM yang didirikan oleh perorangan atau komunitas. 
Umumnya, TBM Mandiri ini terbentuk karena kepedulian dan keinginan seseorang atau komunitas untuk memberikan akses bahan pustaka yang dimiliki kepada masyarakat sekitar. Pembiayaan pun dilakukan secara swadaya. Di TBM Mandiri, TBM tidak hanya sebagai tempat, tapi bisa memperkuat keberadaannya menjadi sebuah lembaga yang memiliki izin operasioanl atau dokumen legalitas; 2) TBM di Satuan Pendidikan atau Lembaga yaitu TBM di Satuan Pendidikan atau Lembaga yang merupakan TBM yang berada atau menginduk di lembaga satuan pendidikan nonformal (seperti PKBM, SKB dan lainnya) atau lembaga lainnya (seperti desa, rumah ibadah, dan lainnya). TBM yang menginduk atau berada di dalam satuan pendidikan atau di sebuah lembaga menjadi bagian atau sarana/tempat atau program dari lembaga tersebut. Perizinan atau dokumen legalitas mengacu pada dokumen lembaga induk. (Kemedikbud, 2018).

Berdasarkan pengertian di atas jika dikaitkan dengan keberadaan taman bacaan masyarakat yang ada di Kabupaten Bandung Barat, dari hasil obervasi yang penulis lakukan jenis taman bacaan masyarakat yang ada merupakan taman bacaan masyarakat mandiri, artinya TBM ini merupakan gagasan dari perseorangan atau swadaya masyarakat. Jadi sampai saat ini belum ada TBM yang berupa PKBM yakni TBM yang menginduk pada lembaga satuan pendidikan non formal yang ada pada Kantor Dinas Pendidikan dan Kebudayaan Kabupaten atau kota.

\section{B. PENGEMBANGAN KOLEKSI}

Pengembangan koleksi secara sederhana dapat diartikan sebagai suatu proses mengindentifikasi kekuatan dan kelemahan koleksi sebuah perpustakaan berkenaan dengan kebutuhan pengguna dan berusaha untuk memperbaiki kelemahan yang ada. Jadi pengembangan koleksi dilakukan pada dasarnya untuk memperbaiki kelemahan- kelemahan koleksi perpustakaan disamping sebagai peningkatan mutu koleksi yang ada untuk memenuhi tuntutan akan informasi-informasi terbaru yang dibutuhkan pengguna.

Dalam melakukan kegiatan pengembangan koleksi ada beberapa azas yang mendasarinya yaitu 1) Relevansi, yakni pemilihan dan pengadaan terkait dengan tujuan dan fungsi perpustakaan sebagai perpustakaan umum propinsi dan koleksi hendaknya harus relevan dan sesuai dengan program dari lembaga induknya dan masyarakat secara luas yang memanfaatken keberadaan perpustakaan; 2) berorientasi kepada pengguna, yaitu pengembangan koleksi harus lebi ditujukan kepada pemenuhan kebutuhan informasi pengguna atau berorientasi kepada pengguna. Dengan demikian kepentingan pengguna menjadi acuan dalam pemilihan atau seleksi pengadaan bahan pustaka. Untuk mengetahui masyarakat pengguna, maka dalam proses pengembangan koleksi dikenal adanya suatu tahap yang disebut dengan analisis masyarakat. Pada tahap ini bermaksud untuk mengetahui masyarakat penggunanya yang meliputi pendidikan, pekerjaan, bidang keahlian dan sebagainya; 3) kelengkapan, artinya koleksi perpustakaan diusahakan tidak hanya terdiri dari buku teks atau koleksi tercetak saja, akan tetapi menyangkut juga koleksi non cetak seperti, kaset, compact disc, CD-Room, DVD Room dan sebagainya. Koleksi perpustakaan harus sesuai dengan masyarakat yang dilayaninya dan semua komponen koleksi mendapat perhatian yang wajar sesuai dengan tingkat prioritas yang ditentukan; 4) kemutakhiran, dalam pengembangan koleksi harus memperhatikan aspek novelty atau kebaharuan koleksi sesuai dengan kebutuhan, tuntutan, dan perkembangan ilmu pengetahuan dan teknologi masa kini. Perpustakaan secara rutin dan teratur mengadakan pembaharuan koleksinya dalam rentang waktu tertentu, khususnya koleksi bidang teknologi dan aplikasinya yang sangat pesat perkembangannya saat ini; 5) aspek kerjasama, artinya dalam pengembangan koleksi unsur-unsur yang terkait harus sinergi sehingga pelaksanaan kegiatan pembinaan koleksi berjalan efektif dan efisien. 
Berbicara tentang pengembangan koleksi, maka perlu dijelaskan tentang koleksi itu sendiri dapat diartikan semua informasi baik dalam bentuk tercetak (printed materials), dalam bentuk non cetak (non book material) mapun dalam bentuk elektronik (electronic) atau digital yang dikumpulkan dan diolah dan disimpan untuk memenuhi kebutuhan pengguna terhadap informasi. Berkaitan dengan koleksi tersebut untuk setiap lembaga perpustakaan mapun pusat informasi akan berbeda dalam hal ketersediaan bentuk koleksinya (tercetak, terekam maupun elektronik). Hal ini juga seperti halnya koleksi atau bahan bacaan untuk taman bacaan masyarakat.

Kemudian tentang koleksi Yunus Winoto, et. al (2019) berdasarkan pendapat Soejono Trimo maupun dan Yuyu Yulia mengelompokkan koleksi sebagai berikut:

\section{Karya tercetak (printed materials)}

Mengenai pengertian koleksi tercetak (printed) adalah suatu sumber informasi yang disajikan dalam bentuk tercetak (printed). Ada jenis koleksi yang termasuk kategori tercetak di antaranya buku dan terbitan berseri.

Pengertian buku jika merujuk pada batasan UNESCO adalah merupakan bahan pustaka yang merupakan suatu kesatuan utuh yang memiliki halaman paling sedikit 49 halaman tidak termasuk kulit maupun jaket buku. Adapun mengenai jenis buku yaitu 1) buku-buku teks (Textbooks); 2) buku-buku referensi (Reference Books); 3) buku-buku bacaan (Supplemantary readings).

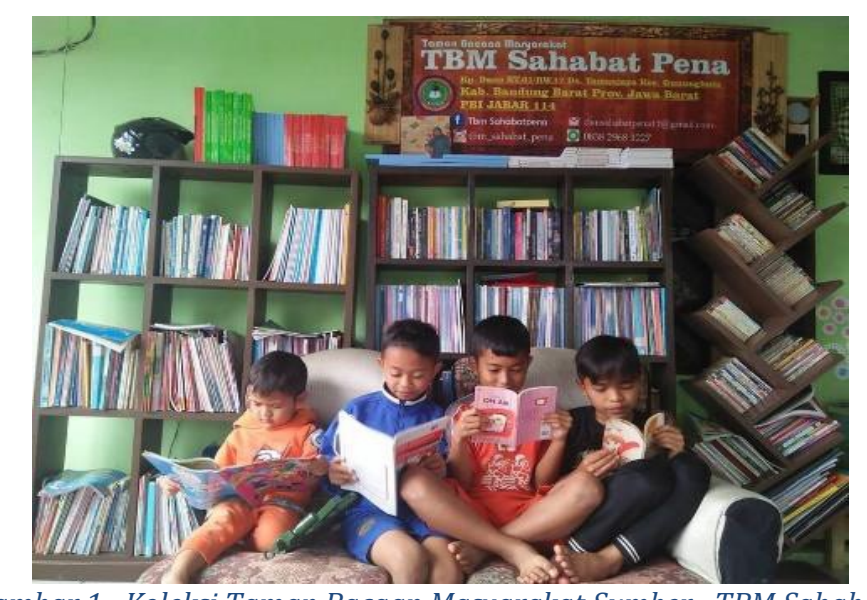

Gambar 1 Gambar 1 : Koleksi Taman Bacaan Masyarakat Sumber : TBM Sahabat Pena, 2019

Terbitan berseri ada yang membedakan lagi menjadi terbitan berseri (serial publication) dan terbitan berkala (periodical publication). Terbitan berseri adalah suatu terbitan yang dilakukan secara berseri atau serial. Mengenai waktu terbitnya bisa berkala (periodik) tapi juga bisa tidak. Misalnya buku-buku seri komunikasi yang ditulis pleh Prof. Dr. Astrid Susanto, itu termasuk dalam kelompok terbitan berseri karena diterbitan secara serial namun waktu penerbitannya tidak tentu. Sedangkan pengertian terbitan berkala adalah suatu terbitan yang dilakukan dengan waktu yang tetap biasa harian, mingguan, bulanan, triwulanan, semester, tahunan, dan lain-lain. Jenis terbitan berkala misalnya surat kabar, majalah, tabloid, dan lain-lain. Catatan : Setiap terbitan berkala (periodical) pasti merupakan terbitan berseri (serial publication) namun tidak setiap terbitan berseri bisa menjadi terbitan berkala. 


\section{Koleksi karya noncetak}

Pengertian koleksi karya non cetak adalah yang dituangkan dalam bentuk rekaman suara, rekaman video, rekaman gambar dan sebagainya. Istilah lain yang dipakai untuk bahan pustaka ini adalah bahan non buku, ataupun bahan pandang dengar. Yang termasuk dalam jenis bahan pustaka ini adalah 1) rekaman suara, yaitu bahan pustaka dalam bentuk pita kaset dan piringan hitam; 2) gambar hidup dan rekaman video. Adapun yang termasuk dalam bentuk ini adalah film dan kaset video; 3) bahan grafika. Mengenai bahan grafika ini terdiri dari dua type yakni bahan pustaka yang dapat dilihat langsung (misalnya lukisan, bagan, foto, gambar, teknik dan sebagainya) dan yang suatu bahan grafika yang harus dilihat dengan menggunakan bantuan alat (misalnya selid, transparansi, dan filmstrip); 4) bahan kartografi. Jenis koleksi yang termasuk dalam kartografi yaitu peta, atlas, bola dunia, foto udara, dan sebagainya.

\section{Koleksi bentuk mikro}

Pengertian koleksi mikro adalah suatu bahan pustaka yang disajikan dalam bentuk film dan penggunaanya harus memakai suatu alat yang disebut micro reader. Bahan pustaka ini biasanya merupakan hasil alih bentuk dari koleksi tercetak seperti buku, surat kabar, majalah, dan lain-lain dimana informasi yang dikandung dalam bahan pustaka tersebut biasanya memiliki nilai informasi yang tinggi dan langka. Ada tiga macam bentuk mikro yang sering menjadi koleksi perpustakaan yaitu 1) mikrofilm, bentuk mikro dalam gulungan film. Ada beberapa ukuran film yaitu $16 \mathrm{~mm}$, dan 35 mm; 2) mikrofis, bentuk mikro dalam lembaran film dengan ukuran 105 mm x 148 mm (standar) dan $75 \mathrm{~mm}$ x $125 \mathrm{~mm}$; 3) microopaque, bentuk mikro di mana informasinya dicetak kedalam kertas yang mengkilat tidak tembus cahaya. Ukuran sebesar mikrofis.

\section{Koleksi dalam bentuk elektronik}

Hadirnya teknologi informasi telah banyak mewarnai berbagai sektor kehidupan manusia termasuk dalam kegiatan penyelenggaraan perpustakaan. Koleksi perpustakaan tidak hanya terbatas pada koleksi tercetak, terekam maupun dalam bentuk mikro. Namun saat ini koleksi perpustakaan dapat disajikan dalam bentuk elektronik. Secara sederhana koleksi elektronik adalah sumber informasi atau bahan bacaan yang disajikan dalam bentuk elektronik dan penggunakan harus menggunakan media seperti komputer, tablet, dan lain-lain. Koleksi elektronik bisa dalam bentuk offline misalnya dalam bentuk CD-ROM maupun on-line yakni terhubung pada jaringan internet. Berkaitan dengan koleksi dalam bentuk elektronik ini saat ini dikenal dengan buku elektronik (e-book) dan jurnal elektronik (e-journal).

Pengembangan koleksi adalah kegiatan yang sifatnya terus menerus atau cyclical. Menurut Evans (2005) ada lima tahapan dalam pengembangan koleksi yaitu tahap analisis kebutuhan yakni suatu tahap untuk mengkaji kebutuhan masyarakat dengan melihat berbagai aspek yang terkait seperti karakteristik masyarakat pengguna, pendidikan, mata pencaharian, kondisi geografis, dan lainlain; tahap kebijakan pengembangan koleksi, setelah diperolehnya profil pengguna dengan berbagai kebutuhannya maka dibuatkan kebijakan koleksi yang akan dikembangkan berdasakan prioritas koleksi serta sumber pendanaannya, dan lain-lain; tahap seleksi bahan pustaka yaitu tahap melakukan pemilihan bahan pustaka dengan memperhatikan prinsip dan falsafah seleksi serta alat bantu seleksi yang digunakan; tahap pengadaan bahan pustaka yakni suatu tahap penyediaan koleksi atau bahan bacaan baik melalui pembelian maupun melalui sumbangan atau donator; tahap penyiangan koleksi yaitu suatu tahap pengeluaran koleksi bahan bacaan yang dianggap sudah jarang dipakai, telah rusak karena faktor kebijakan politik yang melarang terbitnya buyku tersebut; tahap evaluasi yaitu suatu tahapan untuk melakukan penilaian pelaksanaan pengembangan koleksi, evaluasi ini berupa evaluasi proses serta evaluasi hasil. 


\section{KONSEP PENGEMBANGAN KOLEKSI YANG BERBASIS INKLUSI SOSIAL}

Untuk menjelaskan tentang pengembangan koleksi yang berbasis inklusi sosial adalah ada baiknya dijelaskan terlebih dahulu. Adapun mengenai pengertian inklusi sosial diartikan sebagai upaya untuk menempatkan martabat serta kemandirian individu sebagai modal utama dalam mencapai kualitas hidup yang ideal. Dalam konteks pengembangan koleksi yang berbasis inklusi sosial diartikan sebagai kegiatan pengembangan koleksi yang memberikan akses dan kesempatan pada masyarakat pengguna untuk menyampaikan aspirasinya tentang bahan bacaan yang dibutuhkan, sehingga dengan demikian bahan bacaan hasil pengembangan koleksi sesuai dengan tuntutan, kebuhutan dan selera masyarakat penggunanya.

Melalui pendekatan inklusi ini maka diharapkan bahan pustaka hasil pengembangan koleksi bisa dimanfaatkan secara mandiri dan terbuka oleh pengguna untuk meningkatkan pengetahuan dan keterampilan mereka, sehingga pada gilirannya diharapkan kehadiran taman bacaan masyarakat menjadi salah satu bagian dari aktifitas masyarakat sehari-hari dalam rangka meningkatkan kualitas hidup dan kesejahteraan

\section{METODE PENELITIAN}

Pendekatan yang digunakan dalam penelitian ini menggunakan pendekatan kualitatif dengan jenis penelitian fenomenologi. Adapun mengenai pendekatan kualitatif merupakan suatu pendekatan penelitian yang temuan-temuannya tidak diperoleh melalui prosedur statistik atau bentuk hitungan lainnya melainkan berusaha untuk menafsirkan makna suatu peristiwa interaksi tingkah laku manusia dalam situasi tertentu menurut perspektif peneliti sendiri. Berkaitan dengan penelitian kualitatif Moleong (2011:6) menyatakan bahwa penelitian kualitatif adalah penelitian yang bermaksud untuk memahami fenomena tentang apa yang dialami oleh subjek penelitian misalnya perilaku, persepsi, motivasi, tindakan dan lain-lain secara holistik dan dengan cara deskripsi dalam bentuk kata-kata dan bahasa, pada suatu konteks khusus yang alamiah dan dengan memanfaatkan berbagai metode alamiah.

Kemudian mengenai fenomenologi menurut Kuswarno (2009) yaitu studi yang mempelajari fenomena, seperti penampakan segala hal yang muncul dalam pengalaman kita, cara kita mengalami sesuatu dan makna yang kita miliki dalam pengalaman yang kita alami disekitar kita. Fokus perhatian fenomenologi tidak hanya sekedar fenomena akan tetapi, pengalaman sadar dari sudut pandang orang pertama atau yang mengalaminya secara langsung.

Mengenai subjek dalam penelitian ini adalah para pengelola taman bacaan masyarakat (TBM) yang ada di delapan (8) TBM di Kabupaten Bandung Barat. Sedangkan objek penelitiannya adalah kegiatan pengembangan koleksi di taman bacaan masyarakat. Untuk Teknik pengumpulan datanya dilakukan melalui observasi, wawancara dan studi kepustakaan. Teknik analisis datanya dilakukan melalui tahapan reduksi data, penyajian data, serta verifikasi data.

\section{HASIL DAN PEMBAHASAN}

Sebagaimana yang dikemukakan di atas penelitian ini mengkaji pengembangan koleksi yang berbasis inklusi sosial. Penelitian ini dlakukan pada delapan (8) taman bacaan masyarakat di Kabupaten Bandung Barat. Adapun mengenai gambaran taman bacaan masyarakat tersebut yaitu 1) Taman Bacaan Masyarakat (TBM) Cibungur, Pengelola Wildan Awaludin, jenis TBM Mandiri, dengan alamat di Kampung Cibungur RT 01 RW 01 Desa Batujajar Timur, Kecamatan Batujajar Kabupaten Bandung Barat Jawa Barat; 2) Taman Bacaan Masyarakat (TBM) Gunung Ilmu, Pengelola Angga Kurniawan, Jenis TBM mandiri, dengan alamat Kampung Gunung Leutik RT 
01 RW 15 Desa Giriasih, Kecamatan Batujajar, Kabupaten Bandung Barat, Jawa Barat; 3) Taman Bacaan Masyarakat (TBM) Bhakti Mandala Muda, Pengelola Fauzan Erlangggi, jenis TBM Mandiri, dengan alamat Kampung Sekeloa RT 02 RW 10 Desa Cangkorah, Kecamatan Batujajar, Kabupaten Bandung Barat, Jawa Barat; 4) Taman Bacaan Masyarakat (TBM) Bening Saguling, Pengelola Indra Dermawan, jenis TBM Mandiri, dengan alamat Jl.SDN Cianjur RT 08 RW 04 Babakan, Kecamatan Cihampelas, Kabupaten Bandung Barat, Jawa Barat; 5) Taman Bacaan Masyarakat (TBM) Pasir Ipis, Pengelola Lina Marlina, Jenis TBM Mandiri, dengan alamat Kampung Pasir Ipis RT 04 RW 06 Desa Jayagiri, Kecamatan Lembang, Kabupaten Bandung Barat, Jawa Barat; 6) Taman Bacaan Masyarakat (TBM) Tali Rasa Aksara, Pengelola Elpa Andriawan, jenis TBM Mandiri, dengan alamat Kampung Cipongkor RT 03 RW 08 Desa Mekar Sari, Kecamatan Cipongkor, Kabupaten Bandung Barat, Jawa Barat; 7) Taman Bacaan Masyarakat (TBM) Sahabat Pena, Pengelola Ahmad Sumpena, jenis TBM mandiri, dengan alamat Kampung Dano RT 01 RW 17 Desa Tamanjaya, Kecamatan Gununghalu, Kabupaten Bandung Barat, Jawa Barat; 8) Taman Bacaan Masyarakat (TBM) Citapen Berkah, Pengelola Yuda Suhada, jenis TBM Mandiri, dengan alamat di Jln. Babakan Tarogong RT 01 RW 06 Desa Citapen, Kecamatan Cihampelas, Kabupaten Bandung Barat, Jawa Barat.

Kemudian yang menjadi fokus dalam penelitian ini meliputi tahapan analisis kebutuhan pengguna, tahapan kebijakan pengembangan koleksi, tahapan seleksi bahan pustaka, tahapan pengadaan bahan pustaka, tahapan penyiangan bahan pustaka serta tahapan evaluasi pengembangan koleksi. Adapun berdasarkan hasil penelitian dapat dikemukakan sebagai berikut :

\section{A. TAHAPAN ANALISIS KEBUTUHAN MASYARAKAT}

Tahap pertama dalam melakukian kegiatan pengembangan koleksi adalah melakukan analisis kebutuhan pengguna perpustakaan. Tahap ini berkaitan dengan kegiatan "memotret" kondisi masyarakat pengguna yang sebenarnya. Dalam konteks pengembangan koleksi pada taman bacaan masyarakat (TBM) ada berbagai hal yang harus diperhatikan dalam melakukan analisis kebutuhan ini seperti karakteristik masyarakat pengguna, tinggkat pendidikan masyarakat pada umumnya, mata pencaharian, aksesibilitas transportasi, kondisi geografis wilayah, keberadaan unit usaha rumah tangga, kerajinan, dan lain-lain.

Berdasarkan pengamatan peneliti dari delapan (8) taman bacaan masyarakat dilihat dari kondisi geografisnya berbeda-beda, ada TBM yang berada di wilayah industry, ada yang berlokasi di wilayah waduk sagulng, ada yang di daerah pegunungan, tempat wisata, dan lain-lain. Dengan kondisi yang berbeda-beda akan berpengaruh terhadap profil dan kebutuhan masyarakat pengguna taman bacaan masyarakat. Hal ini juga seperti yang diutarakan oleh Indra Dermawan pengelola TBM Bening Saguling yang menyatakan bahwa : "Faktor-faktor yang diperhatikan dalam penyediaan bahan bacaan yang akan disediakan, kami memperhatikan beberapa hal seperti pencaharian, pendidikan, serta jenis bidang usaha dan kerajinan. Apalagi di wilayah kami banyak tanaman seperti eceng gondok yang bertebaran di sekitar waduk untuk bias dikembangkan sebagai bahan untuk kerajinan, sehingga perlu bahan bacaan yang mendukung hal ini." (Sumber: Dermawan, Wawancacara, Desember 2019).

Kemudian dalam melakukan analisis kebutuhan masyarakat ini semua pengelola TBM hanya melakukan secara non formal saja yakni dengan melihat karakteristik pengguna, serta meminta masukan dan saran dari pengguna TBM, tokoh masyarakat mengenai bahan bacaan yang diperlukan di TBM. Dari hasil analisis kebutuhan ini bisa membuat profil pengguna dan mengidentifikasi kebutuhan masyarakat pengguna taman bacaan masyarakat. 


\section{B. TAHAP KEBIJAKAN PENGEMBANGAN KOLEKSI}

Secara teoritis tahapan kebijakan pengembangan koleksi adalah suatu tahapan yang berkaitan dengan penyusunan bahan bacaan yang akan dilakukan oleh perpustakaan atau taman bacaan. Dalam tahapan ini biasanya hanya menguraikan tentang kebutuhan bahan bacaan secara umum seperti jenis subjek bahan bacaan, prioritasnya, alokasi dana yang dibutuhkan sumber pendanaan, cara pembelian, dan lain-lain. Adapun dalam penyusunan kebijakan pengembangan koleksi ini biasanya dilakukan secara tertulis.

Mengenai tahapan kebijakan pengembangan koleksi, berdasarkan pengamatan dan wawancara yang peneliti lakukan nampaknya hampir semua pengelola taman bacaan masyarakat (TBM) belum melakukan penyusunan kebijakan secara tertulis. Setelah memperhatikan karakteristik masyarakat pengguna TBM biasanya pengelola mulai menyusun buku-buku yang akan dibeli sesuai dengan kondisi keuangan mereka. Hal mereka kemukakan karena dalam pengadaan buku di TBM tidak semuanya dari membeli tapi juga merupakan bantuan dari donator atau dari Kantor Dinas Kearsipan dan Perpustakaan KBB.

\section{TAHAPAN SELEKSI BAHAN PUSTAKA}

Tahap selanjutnya dalam kegiatan pengembangan koleksi adalah melakukan pemilihan bahan pustaka. Pengertian seleksi secara sederhana diartikan sebagai proses pengidentifikasian bahan pustaka yang akan ditambahkan pada koleksi yang telah ada di perpustakaan. Berkaitan dengan kegiatan dengan seleksi bahan pustaka yang akan dibeli taman bacaan masyarakat, menurut sebagian pengelola TBM menyatakan mereka memilih bahan bacaan yang berupa buku-buku cerita fiksi, buku pengetahuan dan buku keterampilan atau kerajinan.

Ada beberapa hal yang menjadi pertimbangan pengelola menyediakan buku bacaan seperti buku fiksi, novel dan buku keterampilan dan kerajinan. Hal ini sejalan dengan tujuan dari penyelenggaraan taman bacaan masyarakat yakni untuk menumbuhkan minat baca masyarakat serta untuk meningkatkan pengetahuan dan keterampilan dalam rangka meningkatkan kualitas dan kesejahteraan masyarakat di wilayah taman bacaan masyarakat.

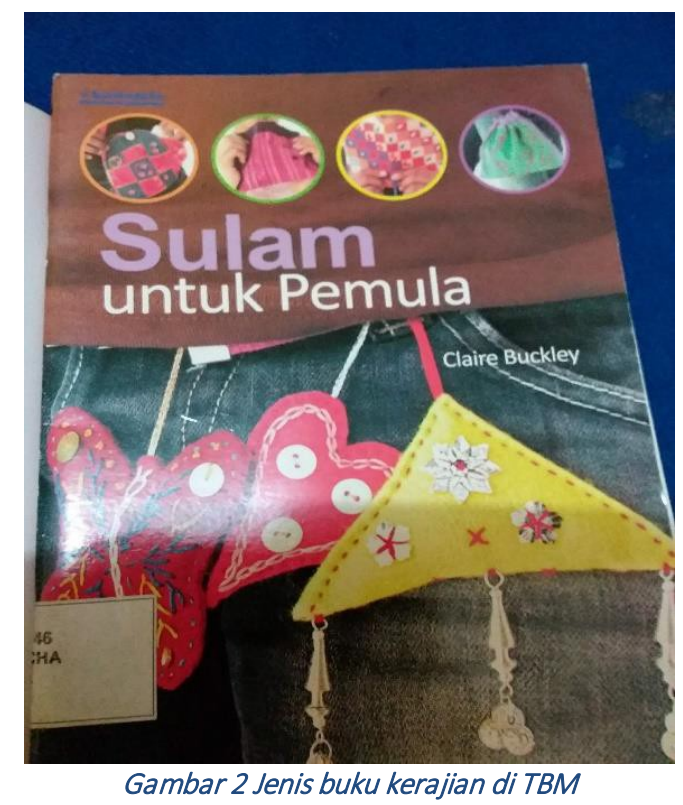




\section{TAHAP PENGADAAN KOLEKSI}

Tahap selanjutnya setelah dilakukan pemilihan bahan pustaka yaitu melakukan pengadaan bahan pustaka. Adapun mengenai pengertian bahan pustaka diartikan rangkaian dalam proses pengembangan koleksi yang berupa perolehan dan penerimaan bahan pustaka yang berupa fisik maupun akses ke sumber daya on line. Berkaitan dengan kegiatan pengadaan bahan pustaka yang dilakukan di taman bacaan masyarakat (TBM) di Kabupaten Bandung Barat berdasarkan observasi dan wawancara dengan pengelola TBM terungkap bahwa dalam pengadaan bahan pustaka selama ini dilakukan melalui dua cara yakni melalui pembelian dan melalui sumbangan dari donator baik perorangan lembaga swasta maupun Lembaga pemerintah.

Mengingat semua taman bacaan masyarakat (TBM) yang ada di kabupaten Bandung Barat merupakan TBM Mandiri yang dirintis oleh individu yang memiliki kepedulian dalam upaya menumbuhkan minat baca masyarakat di sekitarnya, maka dalam penyediaanbahan pustaka melalui pembelian juga dilakukan secara terbatas. Biasanya buku-buku yang dibeli dipriroritaskan untuk buku-buku yang bisa menumbuhkan minat baca atau buku-buku tentang keterampilan. Selain melakukan pembelian para pengelola ini telah tergabung dalam forum TBM KBB biasanya melakukan pendekatan untuk melakukan penjajagan kerjasama dan menjalin kemitraan dengan beberapa pihak. Hal ini sangat penting karena untuk pengembangan koleksi yang hanya mengandalkan dari pembelian yang sumber pendanaanya dari pengelola yang jumlahnya terbatas rasanya sangat sulit. Oleh karena itu beberapa pengelola mengajukan bantuan pada donator baik perorangan, lembaga swasta maupun Kantor Dinas Kearsipan dan Perpustakaan Kabupaten Bandung Barat.

\section{E. TAHAP PENYIANGAN BAHAN PUSTAKA}

Pertambahan buku dan bahan bacaan lainnya di perpustakaan maupun pada taman bacaan masyarakat dari tahun ke tahun akan semakin meningkat. Apalagi jika pengadaan bahan pustaka yang dilakukan suatu taman bacaan masyarakat dalam setiap tahunnya jumlahnya sangat banyak, mada dalam beberapa tahun ke depan koleksnya akan melimpah. Namun demikian dengan bertambahnya koleksi apabila tidak disertai dengan bertambah luasnya ruangan, meningkatkan jumlah SDM, serta lengkapnya fasilitas keberadaan koleksi tersebut akan menjadi persoalan. Oleh karena itu salah satu upaya yang harus dilakukan dengan cara penyiangan bahan pustaka. Adapun mengenai pengertian penyiangan diartikan sebagai proses penarikan bahan pustaka dari tempat penyimpanannya baik untuk sementara maupun untuk selamanya.

Suatu lembaga perpustakaan atau taman bacaan masyarakat melakukan kegiatan penyiangan biasanya didasari beberapa alasan diantaranya adanya beberapa bahan bacaan yang kondisinya rusak sehingga perlu dikeluarkan dari raknya; informasi yang dikandung dalam bahan bacaan tersebut telah usang sehingga perlu ada penggantian sumber informasi lainnya; koleksi atau bahan bacaan tersebut sudah jarang atau tidak pernah dipakai lagi oleh pengguna, sementara tempat penyimpanan bahan pustaka sangat terbatas serta sudah tersedia edisi baru.

Apabila di atas dikemukakan tentang konsep penyiangan dan beberapa alasan dilakukan penyiangan, maka jika dikaitkan dengan keberadaan taman bacaan masyarakat (TBM) yang ada di Kabupaten bandung Barat berdasarkan obervasi yang peneliti lakukan pada delapan (8) taman bacaan masyarakat (TBM) terungkap bahwa semua taman bacaan masyarakat belum pernah melakukan kegiatan penyiangan. Hal ini seperti yang terungkap dari pernyatan salah seorang pengelola TBM yang mengatakan bahwa : "Sampai saat ini kami belum melakukan apa itu yang disebut penyiangan, rasanya sulit boro-boro untuk melakukan penyiangan, selama ini jumlah 
bahan bacaan di TBM jumlahnya masih sangat kurang.” (Sumber: Lina Marlina, Wawancara, Desember 2019).

Jadi berdasarkan hasil observasi dan wawancara dapat disimpulkan bahwa kegiatan penyiangan bahan pustaka pada taman bacaan masyarakat (TBM) yang ada di Kabupaten Bandung Barat belum pernah dilakukan. Hal ini dikarenaka bahan bacaan yang ada di taman bacaan masyarakat jumahnya masih sedikit dan masih dibaca oleh para penggunanya.

\section{F. TAHAP EVALUASI BAHAN PUSTAKA}

Dalam kegiatan pengembangan koleksiEvaluasi merupakan salah satu bagian yang penting dalam kegiatan pengembangan koleksi. Melalui evaluasi berbagai kelemahan baik dalam proses setiap tahapan maupun hasil dari pelaksanan kegiatan pengembangan koleksi dapat diketahui dan bisa segera diatasi dan disempurnakan. Berkaitan dengan evaluasi yang dilakukan para pengelola taman bacaan masyarakat (TBM) terhadap pelaksanaan pengembangan koleksi, biasanya hanya dengan menanyakan pada pengunjung apakah buku-buku yang ada di TBM sudah sesuai dengan kebutuhan mereka serta apakah masih ada buku yang anda butuhkan belum ada di TBM.

Dengan mengajukan beberapa pertanyaan sederhana ini, biasanya pengelola ingin mengetahui apakah kegoiatan pengembangan koleksi yang dilakukan selama ini sudah berjalan sesuai dengan kebutuhan masyarakat pengguna. Dalam kegiatan pengembangan koleksi pihak pengelola sangat terbuka dan menyediakan akses untuk diskusi mengenai buku dan bahan bacaan yang dicari dengan tujuan untuk membangun kemadirian para pengguna dalam mencari sumber informasi dalam rangka meningkatkan pengetahuan dan keterampilan mereka.

\section{KESIMPULAN}

Kegiatan pengembangan koleksi adalah kegiatan yang selama ini dilakukan pengelola taman bacaan masyarakat (TBM), berdasarkan pengalaman para pengelola TBM selama ini dari beberapa tahapan pengembangan koleksi yang dilakukan yaitu dimulai dengan melakukan analisis kebutuhan pengguna dengan karakteristik masyarakat yang dilayani. Dalam kebijakan pengembangan koleksi pengelola tidak melakukannya secara tertulis namun mereka telah menentukan sendiri prioritas subjek buku yang akan dibeli; Untuk penyeleksian bahan bacaan yang akan dipilih berdasarkan pertimbangan pengelola TBM seperti buku fiksi, novel dan bukubuku tentang kerajinan dan keterampilan; Pengadaan bahan bacaan selama ini dilakukan melalui pembelian dan sumbangan dari donatur baik perorangan, lembaga swasta maupun lembaga pemerintah seperti Kantor Dinas Karsipan Dan Perpustakaan KBB; untuk kegiatan penyiangan selama ini semua taman bacaan masyarakat (TBM) di KBB belum melakukan karena koleksinya masih sedikit sedangkan untuk tahap evaluasi pihak pengelola hanya dengan melakukan pertanyaan sederhana pada pengguna mengenai ketersediaan koleksi di TBM dengan bahan bacaan yang sedang dibutuhkan.

\section{DAFTAR PUSTAKA}

A.M, S. (2009). Interaksi dan Motivasi Belajar Mengajar. Jakarta: Rajawali Pers. Balebandung.com. (2016).PerpuSeru Sumbang 93 Komputer ke KBB. Balebandung.Com. Retrieved from http://www.balebandung.com/perpuseru-sumbang-93-komputer-kbb/

Creswell. (1998). Qualitative Inquiry: Choosing Among Five Traditions. USA: Publications. 
Daft, R. L. (2003). Manajemen (5th ed.). Jakarta: Erlangga.

Devega, E. (2017). Teknologi masyarakat indonesia: Malas baca tapi cerewet di medsos. Retrieved December 5, 2019, from

https://www.kominfo.go.id/content/detail/10862/teknologi-masyarakat-indonesia- malas-bacatapi-cerewet-di-medsos/0/sorotan_media

Fauziah, R. (2019). Perpustakaan berbasis inklusi sosial tingkatkan kesejahteraan masyarakat. Retrieved November 27, 2019, from https://www.google.com/amp/s/news.okezone.com/amp/2019/01/03/65/1999638/p erpustakaan-berbasis-inklusi-sosial-tingkatkan-kesejahteraan-masyarakat.

Hamalik, O. (2004). Proses Belajar Mengajar. Jakarta: Bumi Aksara. Hasono. (2008). Pengelolaan Perguruan Tinggi. Yogyakarta: Pustaka Pelajar.

Herdiansyah, H. (2012). Metodologi Penelitian Kualitatif Untuk Ilmu-Ilmu. Sosial.. Jakarta Selatan: Salemba Humanika.

Kemedikbud. (2006). Pedoman Pengelolaan Taman Bacaan Masyarakat. Jakarta: Direktorat Pembinaan Pendidikan Masyarakat.

Kemedikbud. (2018). Petunjuk Teknis Apresiasi Tbm Kreatif-Rekreatif. Jakarta: Direktorat Pembinaan Pendidikan Keaksaraan dan Kesetaraan.

Kuswarno, E. (2009). Metodelogi Penelitian Fenomenologi: Konsepsi, Pedoman dan Contoh Penelitian. Bandung: Widia Padjajaran.

Mallawa, S. (2019). Transformasi perpustakaan berbasis inklusi sosial. Retrieved November 26, 2019, from https:// www.kompasiana.com/amp/

mallawa/5c710979aeebe13c2f5af5c9/tranformasi-perpustakaan-berbasis-inklusi- sosial

Miles, B. M., \& Huberman, A. M. (2007). Analisis Data Kualitatif, Buku Sumber tentang Metode-Metode Baru. Jakarta: Universitas Indonesia Press.

Moleong, L. (2012). Metodologi Penelitian Kualitatif. Bandung: Remaja Rosdakarya.

Mulyana, D. (2010). Metodologi Penelitian Kualitatif: Paradigma Baru Ilmu Komunikasi dan Ilmu Sosial Lainnya. Bandung: Remaja Rosdakarya.

Noor, A. (2009). Management Event. Bandung: Alfabeta.

Prayitno, E. (1989). Motivasi Dalam Belajar dan Berprestasi. jakarta: Departemen Pendidikan dan Kebudayaan Direktorat Jendral Pendidikan Tinggi.

Purwanto, N. (1998). Menuju Keperawatan Profesional. Semarang: Akper Depkes. Retrieved December 4, 2019, from https:// www.perpusnas.go.id /news detail.php?lang=id\&id=190328065053lwHcN3x98C 
Salim, P., \& Salim, Y. (2002). Kamus Bahasa Indonesia Kontemporer. Jakarta: Modern English Press.

Sari, C. W. (2019a). Dari Taman Baca Masyarakat ke Mandiri Ekonomi. Pikiran Rakyat, p. 10. Retrieved from https://www.pikiran-rakyat.com/bandung- raya/2019/03/11/dari-taman baca-masyarakat-ke-mandiri-ekonomi

Sari, C. W. (2019b). Masyarakat Desa di Kabupaten Bandung Barat Tingkatkan Keterampilan Hidup melalui Taman Baca Masyarakat. Pikiran Rakyat, p. 1. Retrieved from https://www.pikiran-rakyat.com/bandung- raya/2019/04/25/masyarakat-desa-di kabupaten-bandung-barat-tingkatkan- $\quad$ keterampilan-hidup-melalui-taman-baca masyarakat

Sugiyono. (2007). Metodologi Penelitian Bisnis. Jakarta: Gramedia. Sutarno, N. S. (2008). Kamus Perpustakaan dan Informasi. Jakarta: Jala.

Uno, H. B. (2011). Teori Motivasi dan Pengukurannya (1st ed.; Junwinanto, ed.). Jakarta: Bumi Aksara.

Winoto, Yunus, et. al (2019). dasar-dasar Pengembangan Koleksi, Kebumen : Intishar Publishing. 